\title{
INTRAVENOUS METHYLPREDNISOLONE IN HTLV-I ASSOCIATED MYELOPATHY/TROPICAL SPASTIC PARAPARESIS (HAM/TSP)
}

\author{
ABELARDO Q-C ARAUJO*, CRISTIANE R. AFONSO **, ANA ClAUDIA B. LEITE * \\ SOLANGE V. DULTRA *
}

SUMMARY - HTLV-I (Human T-lymphotropic virus type I) associated myelopathy/tropical spastic paraparesis (HAM/TSP) is an immunomediated myelopathy induced by the HTLV-I. Some patients, specially those from Japan, seem to have a good response to steroid treatment. However, this has not been found in other regions of the world. High dose intravenous methylprednisolone has been used with success in patients with relapses of multiple sclerosis (MS), another autoimmune disease of the central nervous syrtem. To test the effectiveness of methylprednisolone in patients with HAM/TSP, we devised an open trial in 23 patients. We found a very limited benefit of this form of treatment in these patients. Only one patient, who had the shortest disease duration (five months) in the whole group, showed a sustained benefit. We speculate that those patients with a shorter history, with presumably less demyelination and more inflammatory lesions, would show a better response to immunossupressive treatments.

KEY WORDS: HTLV-I, tropical spastic paraparesis, methylprednisolone.

\section{Metilprednisolona endovenosa na mielopatia associada ao HTLV-I/Paraparesia Espástica Tropical (MAH/PET)}

RESUMO - A mielopatia associada ao protovirus $T$-linfotrópico humano (HTLV-I), também conhecida como paraparesia espástica tropical associada ao HTLV-I (MAH/PET), constitui enfermidade imunomediada desencadeada pela infecção pelo HTLV-I. Nesta condição tem sido demonstrada, particularmente em pacientes japoneses, boa resposta clínica à terapêutica com corticosteróides. Este efeito benéfico todavia não foi encontrado em todas as regióes do mundo. Pulsoterapia com metilprednisolona endovenosa tem sido utilizada com sucesso em pacientes com esclerose múltipla, outro exemplo de doença auto-imune do sistema nervoso central, especialmente durante as fases de exacerbação da doença. Objetivando testar a eficácia da pulsoterapia com metilprednisolona em pacientes com MAH/PET, conduzimos estudo aberto em 23 doentes. Não constatamos efeito benéfico significativo desta forma de tratamento na maioria dos enfermos estudados. Apenas um dos pacientes, o qual exibia o menor tempo de duração de doenca (cinco meses), obteve benefício a longo prazo. Acreditamos que tratamentos imunossupressivos devam ser de maior utilidade naqueles doentes com menor tempo de evoluçăo, nos quais, possivelmente, há preponderância do processo inflamatório sobre o desmielinizante.

PALAVRAS-CHAVE: HTLV-I, paraparesia espástica tropical, metilprednisolona.

* HTLV Associated Neuropathies Unit, Evandro Chagas Hospital, FIOCRUZ, Rio de Janeiro; ** Instituto de Neurologia Deolindo Couto, Universidade Federal do Rio de Janeiro. Aceite: 9-dezembro-1992.

Dr. Abelardo de Queiroz-Campos Araújo - Unidade de Neuropatias Associadas ao HTLV, Hospital Evandro Chagas, FIOCRUZ - Av. Brasil 4365 - 21040-361 Rio de Janeiro RJ - Brasil Fax 5521-5909988. 
The human T-lymphotropic virus type I (HTLV-I) has been recently found to be associated with some diseases of obscure origin such as pulmonary alveolitis, uveitis, Sjögren syndrome, arthropathies, vasculitis, ichthyosis, cryoglobulinemia and monoclonal gammopathy 11. Despite these protean manifestations the only two diseases unequivocally associated to HTLV-I infection are adult T-cell leukaemia/lymphoma (ATLL) and HTLV-I-associated myelopathy/tropical spastic paraparesis (HAM/TSP)17,19. Increasing evidences point to an immunomediated mechanism as responsible for the neurological lesions found in patients with HAM/TSP 2,8. In addition, according to Osame's group in Japan, more than 50\% of these patients have an excellent or good response to treatment with steroids 11,12,14. There have been, however, some controversies on this matter with negligible or no response to these drugs according to other studies $4,7,16,18,20$.

High dose intravenous methylprednisolone has been used with success in patients with multiple sclerosis (MS), another autoimmune disease of the central nervous system 5 . To test the effectiveness of methylprednisolone in patients with HAM/TSP, we devised an open trial.

\section{PATIENTS AND METhods}

Twenty-three previously untreated patients with progressive spastic paraparesis and HTLV-I antibodies in both serum and cerebrospinal fluid (HAM/TSP patients) were evaluated. Their serological status was confirmed by indirect immunofluorescence (using the MT-2 and C91-PL cell lines) and western blot analysis (Cambridge Biotech, Worcester, MA). The group of patients consisted of 12 women and 11 men with a mean age of 47 years, a mean duration of disease of 7.3 years and a mean score in the Kurtzke's disability status scale (DSS) 10 of 4.5 .

The trial was opened. The treatment consisted of a five day course of $1 \mathrm{~g}$ intravenous methylprednisolone. The patients were evaluated clinically the day before starting the drug and 1,30 and 60 days after finishing it. The following clinical parameters were considered in the evaluation: pain, sphincter dysfunction, sensory loss, spasticity in the lower limbs, increased deep reflexes in the upper and lower limbs, bilateral Babinski's sign and DSS. The percentage of improvement in each clinical parameter was calculated considering the number of patients who improved (or the mean DSS) at each day of examination in relation to the total number of patients who presented that clinical finding before the starting of the treatment.

\section{RESULTS}

The Table summarizes the effect of treatment in the group, considered as a whole.

Table. Effect of methylprednisolone in 23 HAM/TSP patients.

\begin{tabular}{lcccccrr}
\hline $\begin{array}{c}\text { Clinical } \\
\text { parameters }\end{array}$ & $\begin{array}{c}\text { Pre- } \\
\text { treatment } \\
(\mathrm{N})\end{array}$ & $\begin{array}{c}\text { Day } \\
\mathbf{1}\end{array}$ & $\begin{array}{c}\text { \% of } \\
\text { improve- } \\
\text { ment }\end{array}$ & $\begin{array}{c}\text { Day } \\
30 \\
(\mathrm{~N})\end{array}$ & $\begin{array}{c}\text { \% of } \\
\text { improve- } \\
\text { ment }\end{array}$ & $\begin{array}{c}\text { Day } \\
60 \\
(\mathrm{~N})\end{array}$ & $\begin{array}{c}\text { \% of } \\
\text { improve- } \\
\text { ment }\end{array}$ \\
\hline Pain & 14 & 10 & 28.6 & 12 & 14.3 & 13 & 7.1 \\
Sphincter dysfunction & 22 & 22 & 0 & 22 & 0 & 22 & 0 \\
Spasticity & 22 & 21 & 4.5 & 21 & 4.5 & 21 & 4.5 \\
Increased reflexes in UL & 21 & 19 & 9.5 & 20 & 4.8 & 21 & 0 \\
Increased reflexes in LL & 22 & 21 & 4.5 & 21 & 4.5 & 21 & 4.5 \\
Babinski's sign & 21 & 20 & 4.8 & 20 & 4.8 & 21 & 0 \\
Sensory loss & 15 & 15 & 0 & 15 & 0 & 15 & 0 \\
DSS (mean) & 4.52 & 4.47 & 1.1 & 4.47 & 1.1 & 4.47 & 1.1 \\
\hline
\end{tabular}

(N), number of patients; DSS, Kurtzke's Disability Status Scale; \% of improvement, number of patients who improved in some finding at that day (or mean DSS) / number of patients with that finding in the first evaluation (or difference of mean DSS) $\times 100$. 


\section{COMMENTS}

Treatment with methylprednisolone, considering these 23 HAM/TSP patients as a whole, had, at most, a very limited benefit, specially at long term (Table). There was no improvement at all in the sphincter disturbances and in the sensory loss. The remainder neurological parameters improved in the minority of patients and the greatest improvement was seen one day after the end of the treatment. Therapy improved algic symptoms most than any other. It was very clear that those patients who had some benefit returned to their previous state as time went by. Therefore, the benefit of the therapy was transient in most patients, apart from one patient in whom the pain, the spasticity and the hyperreflexia in the lower limbs disappeared, and remained so after two months of therapy. This man was the one who had the shortest duration of the disease in the whole group (five months of disease).

Our results agree with those of Duncan and Rudge 6 who found that methylprednisolone did not have any sustained benefit in nine patients with HAM/ TSP. In their series most of the patients showed only a short term benefit. Since our study, like the one of Duncan and Rudge 6 , was not blinded, a placebo effect may have contributed to the short term benefits in some patients. Howe. ver it is interesting that the patient in our series who had the best response to therapy was the one with the shortest duration of the disease. According to Iwasaki, in a series of 10 autopsied patients 9 , cases of HAM/TSP with more than three years of duration had more demyelination and gliosis and less inflammation in the spinal cord. In addition, apparently those patients submitted to immunossupression had a lesser degree of inflammatory reaction $\mathbf{9}$. Consequently, we could speculate that those patients with a shorter history, with presumably less demyelination and more inflammatory lesions, would benefit more of immunossupressive treatments such as the used in the present work. This hypothesis would also explain why therapy with steroids is apparently more effective in Japan than in the tropics 12,16,18,20. This could happen because a large amount of cases of HAM/TSP in Japan is presumably due to blood transfusions, which causes a disease with a shorter incubation period 13. In Brazil, as well as in many tropical regions, most cases of HAM/TSP are probably sexually acquired 1. Our patients had a mean duration of disease of more than 7 years. This could be the possible explanation for their poor response to methylprednisolone. Only larger randomized double blind controlled studies would be able to confirm if this hypothesis is correct.

In Brazil HAM/TSP is the most common cause of spastic paraparesis of obscure origin 3 . It is extremely important continuing to pursuit some form of treatment for these patients since their disability represents a significant economical and social problem particularly in tropical countries.

Acknowledgements - We thank Drs. Maria José de Andrada-Serpa and Doris Schor for

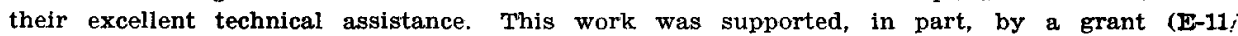
150.763/91) from the Rio de Janeiro State Research Foundation (FAPERJ).

\section{REFERENCES}

1. Araújo AQ-C. Do protovírus T-linfotrópico humano e de suas manifestações neurológícas. Thesis. Niterói: Universidade Federal Fluminense, 1991.

2. Araújo AQ-C, Freitas MRG, Nascimento $O$. Da patogenia das neuropatias associadas ao protovíruos T-linfotrópico humano (HTLV-I). Rev Bras Neurol 1992, 57-63.

3. Araújo AQ-C, Ali A, Newell A, Dalgleish AG, Rudge P. HTLV-I infection and neurological disease in Rio de Janeiro. $J$ Neurol Neurosurg Psychiatry 1992, 55:153-155.

4. Bhagavati S, Ehrlich G, Kula RW, Kwok S, Sninky J, Udani V, Poiesz BJ. Detection of human T-cell lymphoma/leukemia virus type I DNA and antigen in spinal fluid and blood of patients with chronic progressive myelopathy. N Engl J Med 1988, 318:1141-1147.

5. Compston A. Methylprednisolone and multiple sclerosis. Arch Neurol 1988, 45:669-670.

6. Duncan J, Rudge P. Methylprednisolone therapy in tropical spastic paraparesis. J Neurol Neurosurg Psychiatry 1990, 53:173-174.

7. Gout O, Gessain A, Bolgert F, Saal F, Tournier-Lasserve E, Lasneret J, Caudie C, Brunet P, De-Thé G, Lhermitte F, Lyon-Caen $O$. Chronic myelopathies associated with human T-lymphotropic virus type I. Arch Neurol 1989, 46:255-260. 
8. Itoyama Y, Minato S, Kira J-I, Goto I, Okochi K, Yamamoto N. Immunological aspects of HTLV-1-associated myelopathy (HAM). In: Román GC, Vernant J-C, Osame M. HTLV-I and the nervous system. New York: Alan R. Liss, 1989, p 287-295.

9. Iwasaki $Y$. Pathology of chronic myelopathy associated with HTLV-I infection (HAM/ TSP). J Neurol Sci 1990, 96:103-123.

10. Kurtzke JF. Further notes on disability evaluation in multiple sclerosis, with scale modifications. Neurology 1965, 15:654-661.

11. Osame M. Review of WHO Kagoshima meeting and diagnostic guidelines for HAM/TSP. In: Blattner W, ed. Human Retrovirology: HTLV. New York: Raven Press, 1990, p 191-197.

12. Osame $M$, Igata A, Matsumoto $M$. HTLV-I-associated myelopathy (HAM) revisited. In: Román GC, Vernant J-C, Osame M. HTLV-I and the Nervous System. New York: Alan R. Liss, 1989, p 213-223.

13. Osame $\mathbf{M}$, Janssen $R$, Kubota $H$, Nishitani $H$, Igata A, Nagataki S, Mori $M$, Goto $I$, Shimabukuro $H$, Khabbaz $R$, Kaplan J. Niationwide survey of HTLV-I-associated myelopathy in Japan: association with blood transfusion. Ann Neurol 1990, 28:50-56.

14. Osame $\mathbf{M}$, Matsumoto $\mathbf{M}$, Usuku K, Izumo S, Ijichi N, Amitani H, Tara M, Igata A. Chronic progressive myelopathy associated with elevated antibodies to human T-lymphotropic virus type $I$ and adult T-cell leukemia-like cells. Ann Neurol 1987, 21:117-122.

15. Osame M, Usuku K, Izumo S, Ijichi $\mathbf{N}$, Amitani H, Igata A, Matsumoto M, Tara M. HTLV-I associated myelopathy, a new clinical entity. Lancet 1986, 1:1031-1032.

16. Rodgers-Johnson P, Morgan OStC, Mora C, Sarin P, Ceroni M, Piccardo P, Garruto RM, Gibbs CJ, Gajdusek DC. The role of HTLV-I in tropical spastic paraparesis in Jamaica. Ann Neurol 1988, 23(Suppl):S121-S126.

17. Román GC, Osame M, Igata A. HTLV-I-associated myelopathy (HAM) and tropical spastic paraparesis (TSP). In: Román GC, Vernant J-C, Osame $M$, eds. HTLV-I and the Nervous System. New York: Alan R. Liss, 1989, p 93-98.

18. Vernant JC, Maurs L, Gessain A, Barin F, Gout O, Delaporte JM, Sanhadji K, Buisson G, De The G. Endemic tropical spastic paraparesis associated with human T-lymphotropic virus type I: a clinical and seroepidemiological study of 25 cases. Ann Neurol 1987, 21:123-130.

19. Yoshida M, Miyoshi I, Hinuma $Y$. Isolation and characterization of retrovirus from cell lines of human adult $T$-cell leukemia and its implication in the disease. Proc Natl Acad Sci USA 1982, $79: 2031-2035$.

20. Zaninovic V, Arango C, Rodgers-Johnson $P$, Concha $\mathbf{M}$, Corral $\mathbf{R}$, Barreto $\mathbf{P}$, Borrero I, Garruto RM, Gibbs CJ, Gajdusek DC. Tropical spastic paraparesis in Colombia. Ann Neurol 1988, 23(Suppl):S127-S132. 